\title{
Dolaylı ve Dolaysız Vergilerin Ekonomik Aktiviteler Üzerindeki Simetrik ve Asimetrik Etkileri
}

Hüseyin KARAMELIKLi²

Makale Gönderim Tarihi: 28.12.2017

Makale Kabul Tarihi: 24.09.2018

\section{Öz}

Bu çalıșmada dolaylı ve dolaysız vergilerin ekonomik aktiviteler üzerindeki etkileri araștırılmaktadır. Vergiler ile ekonomik aktiviteler arasında ilișki çoğunlukla simetrik varsayımlar üzerinden yapılmaktadır. Makroekonomik değișkenler arasındaki ilișkilerin asimetrik yönünün hesaba katılmadığı çalıșmalar yanlıș politikalar uygulanmasına sebep olabilmektedir. Bu nedenle bu çalıșmada dolaylı vergiler ve dolaysız vergiler ile iktisadi aktiviteler arasındaki uzun dönemli ilișki, doğrusal olmayan gecikmesi dağııılmıș otoregresif model (NARDL) kullanılarak incelenmektedir. Vergideki artıșların ekonomik aktivitelere etkili olduğu görünürken azalıșı anlamlı bir etki yapmadığı ortaya çıkmıștır. Kısa dönemde vergilerin (dolaysız) artıșı ekonomik aktivitelere olumsuz etki yaparken uzun dönemde bunun tersi bir durum ortaya çıkmaktadır.

Anahtar Kelimeler: Dolaysız Vergi, Dolaylı Vergi, NARDL, Ekonomik Aktiviteler

JEL Kodları: H2O, H21

\section{The Symmetric and Asymmetric Effects of Direct and Indirect Taxes on} the Economic Activities

\section{Abstract}

In this study, the effects of direct and indirect taxes on economic activities are being investigated. The relationship between taxes and economic activities is mostly based on symmetric assumptions. Studies

Bu makalenin bir önceki sürümü Uluslararası TEK Konferansında sunulmuștur.

2 Doç Dr, Karabük üniversitesi İ̈BF iktisat bölümü, hakperesł@gmail.com, orcid: 0000-00017622-0972 
that do not involve asymmetric feature of the relationships between macroeconomic variables can lead to the implementation of wrong policies. For this reason, the long-run relationship between indirect taxes and direct taxes and economic activities in this study is examined by using a nonlinear autoregressive distributed lag model (NARDL). Moreover, while the tax increases seemed to have an impact on economic activity, the decline did not seem to have a significant effect. In the short term, the (direct) increase of the tax has a negative effect on the economic activities, whereas the opposite situation occurs in the long run.

Keywords: Direct Tax, Indirect Tax, NARDL, Economic Activities

JEL Classification Codes: H2O, H2 1

\section{Giriș}

Vergilerin ülke ekonomi üzerindeki etkisi, iktisatçıların araștırma konularından biridir. Vergi türlerinin ekonomik aktiviteler üzerine etkisi hem teorik hem de uygulamalı olarak sıkça incelenen konular arasındadır. Buna ilaveten söz konusu etkiler kısa ve uzun dönemde farklılık gösterebilir ve birçok araștırmada dikkate alınmıștır. Diğer yandan piyasada mevcut bulunan yapıșkanlıklar ve vergilerin ekonomik yapıyı değiștirme gücü nedeniyle vergi bileșenlerinin asimetrik etkisi de aydınlatılması gerekmektedir. Vergilerin (dolaylı ve dolaylı olmayan) ayrı ayrı incelenmesi ve uzun dönemde üretim üzerindeki simetrik veya asimetrik etkisi merak konusudur.

Vergi gelirleri, Türkiye'de kamu harcamaları, kamu iktisadi teșebbüsleriyle yeni kamu hizmetlerinin kurulması, kamu yatırımları, askeri harcamalar ve sosyal harcamaların finansmanını sağlayan en önemli ve en büyük gelir kaynağı olarak bilinmektedir (ilhan, 2007). Vergi, ülkelerin iktisadi alanları ve sosyo-politik faaliyetlerinin odak noktası olarak görülmektedir. Bir tür kaynak paylașım aracı olan vergi, yapısı itibariyle, sosyal dönüșümlerin de etkisiyle, zamanla değișebilmekte ve yeni bir hale gelebilmektedir (Gökbunar, 1997).

Kișilerin gelirlerinden alınan vergiler gibi, harcamalar üzerinden alınan vergilerde de birtakım düzenlemeler yapılarak yoksullukla mücadele sağlanabilmektedir. Yapılan birtakım harcamaların üzerinden alınan vergiler; Katma Değer Vergisi (KDV), Özel Tüketim Vergisi (ÖTV), Özel İletișim Vergisi (ÖiV) gibi çeșitli vergiler genel anlamda kișinin șahsi durumuyla alakalı olmayan vergi türleridir. Bu vergi türlerinin gelir dağılımı üzerinde yıkıcı etkilere sebep olduğu iddia edilmektedir. Bu 
yüzden vergi sisteminde dolaylı vergilerden dolaysız vergi yapısı sistemine geçilmesi önerilmektedir (Aydin ve Türgay, 2011 1). Dolaylı vergilerde ise durum; hem vergilendirme adaleti neticesinde ortaya çıkan sakıncalar incelendiğinde hem de gelișmiș ülkelerin ekonomilerindeki payı dikkate alındığında Türkiye'de dolaylı vergi türünün olușturduğu boyut, olumsuz bir durumun ortaya çıktığını göstermektedir (Susam ve Oktayer, 2005). Vergi gelirleri içerisinde dolaysız vergi türünün payının büyümesi vergilendirmedeki adaletsizlik olarak karșımıza çıkmaktadır (Karabulut, 2003). Bu adaletsizliğin giderilmesi için dolaylı vergi türlerinin geliri düșük olan vatandașların tükettiği mal ve hizmetlerden alınamaması gerekmektedir (Aliyev ve Hopoğlu, 2016).

Keynesyen iktisadi görüșe göre, vergilerde bir artıș hane halkının harcanabilir gelirini azaltmaktadır. Gelir azalıșı ise, toplam talep üzerinde daraltıcı etki yaratmaktadır. Tam istihdam düzeyinde olamayan bir ekonomide talep azalıșı ise, üretimde azalmaya neden olmaktadır. Keynesyen ekonomik model kapsamında milli gelirle vergi arasında negatif yönlü bir ilișki söz konusudur.

Dolaysız vergiler, kâr ve gelir üzerinden alındığından kaynaklar devlete aktarılmaktadır. Dolaysız vergi ekonomik aktiviteler üzerinde negatif etkiye sebep olması beklenmektedir. Dolaylı vergiler ise, tüketicilerden tahsil edilirken harcanabilir geliri azaltıyor. Fakat bu durum üreticilerin üzerindeki vergi yükünün hafiflemesine yardımcı olmaktadır. Bu nedenle dolaysız vergilerin ekonomik aktiviteler üzerindeki etkisinin belirlenmesi önem kazanmaktadır. Bu çalıșmada dolaylı ve dolaysız vergilerin, ekonomik aktiviteler üzerine olan uzun dönemli etkisi hem doğrusal hem de doğrusal olmayan yöntemle analiz edilmektedir.

\section{ILGILI LITERATÜR}

Siverekli ve Demircan (2003) harcamalar üzerinden alınan dolaylı vergilerin, adaleti sağlamaya yönelik olarak lüks tüketimlerin azaltılması, bunun sonucunda da tasarrufun teșvik edilmesiyle birlikte ekonomik büyüme ve kalkınmaya dolaylı olarak da olsa etkilerinin olduğu tespit etmișlerdir.

Koch vd. (2005) vergi ile ekonomik büyüme arasındaki ilișkinin bazı teorik araștırmaların aksine, güçlü bir ilișki olduğunu belirlemișler. Mamatzakis (2005) çalıșmasına göre ekonomik büyüme, vergi gelirleri üzerinde olumsuz bir etkiye sahiptir. Açıkgöz (2008) nedensellik testi sonucuna göre vergilendirme yapısıyla ekonomik büyüme arasında 
tek yönlü bir ilișki olduğunu tespit edilmiștir. İlișki yönü ekonomik büyümeden dolaylı ve dolaysız vergi gelirlerinin toplamdaki vergi gelirleri içerisindeki payına doğru bulunmuștur. Çalıșmanın sonucunda dolaysız vergi gelirlerinin GSYiH'ya oranlanmasından büyümeye doğru tek yönlü olarak bir nedensellik ilișkisi olduğu tespit edilmiștir.

Göçer vd. (2010) vergileri hem dolaylı ve dolaysız olarak ikiye ayırarak analiz etmiș. Analizin sonucunda veriler arasında eșbütünleșme ilișkisinin var olduğu, diğer bir ifadeyle verilerin uzun dönemde beraber hareket ettiklerini tespit edilmiștir. Bu çalıșmada dolaylı ve dolaysız vergiler ile ekonomik büyüme arasında uzun dönemde anlamlı ve pozitif bir ilișkinin varlığı bulunmuș, dolaysız vergilerin dolaylı vergilerden daha büyük etkiye sahip olduğu görülmüștür. Mercan vd. (2010) benzer sonuca ulașmıștır. Onların çalıșmasında da dolaysız vergilerin dolaylı vergilere nazaran daha büyük etkiye sahip olduğu görülmüștür. Paksoy ve Bakan (2010) çalıșmasında, 1980 yılı sonrasında Türkiye'de uygulanan vergilendirme politikaları ve ekonomik büyüme üzerindeki etkileri incelenmiștir. Vergi gelirleri ile ekonomik büyüme arasındaki ilișki beklenen ölçüde olmamıștır. Güvenek vd. (2010) dolaylı vergilerin fiyat seviyesi üzerinde etkisini incelemișler ve elde edilen bulgulara göre TÜFE'de meydana gelen bir değișme dolaylı vergi gelirlerinde değișmeye yol açarken dolaylı vergilerin de TÜFE üzerinde değișikliğe sebep olmaktadır.

Umutlu vd. (2011) dolaylı vergi ile büyüme arasında nedensellik ilișkisini test etmișlerdir. İç borçlanmanın büyümeyi negatif etkilediği, toplanan vergiler ise ekonomik büyüme üzerinde herhangi bir etki yaratmadığını saplamıșlardır. Ilaboya ve Mgbame (2012) Nijerya ekonomisindeki dolaylı vergiler ve büyüme arasında negatif bir ilișki olduğunu gösterdiler. Mahmood ve Chaudhary'nin (2013) çalıșmasında uzun ve kısa dönemli ilișkiler araștırılmıștır. Çalıșan kiși bașına doğrudan yabancı sermaye yatırımlarının ve gayri safi yurtiçi hasılanın vergi geliri üzerinde olumlu ve önemli bir etkiye sahip oldukları tespit edilmiștir.

Munir ve Sultan (2016) Pakistan'da dolaylı vergi, uluslararası ticaret, satıș vergisi ve diğer dolaylı vergilerin reel GSYiH üzerinde pozitif ve anlamlı bir etkiye sahip olduğunu göstermiștir. Bu araștırmada ÖTV ile reel GSYiH arasında negatif ilișki bulunmuștur. Bununla birlikte, kısa vadede satıș vergisi, uluslararası ticaret ve diğer vergilendirmede pozitif bir ilișki söz konusudur. 
Çalıkay (2017) iktisadi büyümenin vergi yükü üzerindeki etkisini ARDL yöntemi ile araștırmıștır. Onun çalıșmasına göre gayri safi yurtiçi hasıla arttıkça vergi yükü de artmaktadır. Organ ve Ergen (2017) aynı yöntemi kullanarak Türkiye'de vergi yükü ile ekonomik büyüme arasında ilișkiyi incelemișler. Çalıșmanın sonunda vergi yükü ve ekonomik büyümenin eș-bütünleșme ilișkisine sahip olduğunu saptanmıș ve iki değișken arasında uzun dönemde negatif bir ilișki olduğu bulunmuștur. Eren vd. (2018) Hacker ve Hatemi nedensellik testi uygulayarak dolaylı vergi gelirlerinden kalkınmaya doğru tek yönlü nedensellik ilișki tespit etmișlerdir. Değișkenler arasındaki nedensellik ilișkilerini dönemlere ayırarak araștıran Breitung ve Caldelon frekans alanı nedensellik testi sonuçlarına göre toplam vergi gelirlerinden büyümeye kısa ve orta dönemde, dolaysız vergi gelirlerinden büyümeye kısa dönemde ve büyümeden dolaylı vergi gelirlerine uzun dönemde tek yönlü ilișkiler bulmușlar. Juliana (2018) Nijerya için yaptığı araștırmada vergi gelirlerinin ekonomik büyümeye pozitif bir etki yaptığını ortaya koymuștur.

\section{Metodoloji ve Model}

Temiz' in (2008) çalıșmasında așağıdaki model belirlenmiștiir:

$$
\text { IPI }_{t}=\alpha_{0}+\alpha_{1} \text { RDIRECT }_{t}+\alpha_{2} \text { RINDIRECT }_{t}+\epsilon_{t}
$$

Aylık veriler kullanıldığından ve GSYH verileri aylık olarak temin edilemediğinden ekonomik aktiviteleri temsilen sanayi üretim endeksi (IPI) kullanılmıștır. Sabit fiyatlar ile hesaplanmıș dolaylı ve dolaysız vergiler ise, sirasıyla RINDIRECT ve RDIRECT olarak gösterilmektedir.

Keynes (1936, p. 314) ekonomik değișkenler arasındaki asimetrik ilișkiye vurgu yapmıș̦ır ${ }^{3}$. Shin vd. (2014) ise, insan davranıșların doğasında asimetri olduğundan makroekonomik değișkenlere yansımasının olduğunu iddia etmișlerdir4. Ayrıca Kahneman ve Tversky (1979); Shiller $(1993,2005)$ makroekonomik modellerin incelenmesinde asimetrik ilișkilerin dikkate alınması gerekliliğini ileri sürmüșlerdir.

Modelde bulunan değișkenler arasındaki asimetrik ilișkinin göz ardı edilmemesi amacıyla NARDL (nonlinear autoregressive distributed

3 "The substitution of a downward for an upward tendency often takes place suddenly and violently, whereas there is, as a rule, no such sharp turning point when an upward is substituted for a downward tendency".

4 "The nonlinearity of many macroeconomic variables and processes has long been recognized and nonlinearity is endemic within the social sciences and that asymmetry is fundamental to the human condition." 
lag) yöntemi uygulanmıștır. NARDL modeli Shin vd.(2014) tarafından Pesaran vd. (2001) ARDL modeli kullanılarak geliștirilmiștir. Bu modelde asimetrik özelliği tașıyan değișken, artıș ve azalıș olarak iki ayrı değișkene ayrılmakta ve tahmin edilmesi gereken model yeniden düzenlenmektedir. Hata düzeltme modelinde bağımlı değișkenin kısa dönemde diğer değișkenlerin yanı sıra uzun dönem dengeden sapmaların da bir fonksiyonu kabul edilmektedir. Așağıdaki denklem hata düzeltme modelimizi (Error Correction Model) göstermektedir:

$$
\begin{gathered}
\Delta \mathrm{IPI}_{t}=\beta_{0}+\sum_{j=1}^{p} \beta_{1 j} \Delta \operatorname{IPI}_{t-j}+\sum_{j=0}^{q} \beta_{2 j} \Delta \operatorname{RDIRECT}_{t-j}+\sum_{j=0}^{m} \beta_{3 j} \Delta \operatorname{RINDIRECT}_{t-j} \\
+\gamma_{1} \operatorname{DUMMY}_{t}(2)+\theta \epsilon_{t-1}+e_{t}
\end{gathered}
$$

Burada $\Delta$ değișkenlerin birinci farkını ve $\varepsilon$ hata düzeltme terimini göstermektedir. Hata düzeltme terimi (1) numaralı denklemde gösterilen uzun dönemli eșbütünleșme modelinin artık terimleridir. Böylece uzun dönem ilișki tahmin sonucunda elde edilen artıkların gecikmeli değerleri, kısa dönem modele eklenerek, hata düzeltme modeli olușturulmaktadır. (1) ve (2) numaralı denklem birleștirildiğinde ise, așağıdaki denklem elde edilmektedir:

$$
\begin{aligned}
\Delta \mathrm{IPI}_{t}=\psi+ & \eta_{0} \mathrm{IPI}_{t-1}+\eta_{1} \operatorname{RDIRECT}_{t-1}+\eta_{2} \operatorname{RINDIRECT}_{t-1}+\sum_{j=1}^{p} \beta_{1 j} \Delta \operatorname{IPI}_{t-j} \\
& +\sum_{j=0}^{q} \beta_{2 j} \Delta \operatorname{RDIRECT}_{t-j}+\sum_{j=0}^{m} \beta_{3 j} \Delta \operatorname{RINDIRECT}_{t-j}+\gamma_{1} \mathrm{DUMMY}_{t}+e_{t}
\end{aligned}
$$

(3) numaralı denklem için $\psi=\beta_{0}-\theta \alpha_{0}, \eta_{0}=\theta, \eta_{1}=-\theta \alpha_{1}$ ve $\eta_{2}=-\theta \alpha_{2}$ koșulları geçerlidir. Dolaylı vergiler, dolaysız verailer ve sanayi üretiminin uzun dönem katsayıları ise, sırasıyla ve $\theta=\eta_{0}, \alpha_{1}=-\frac{\eta_{1}}{\theta}, \alpha_{2}=-\frac{\eta_{2}}{\theta}$ kısa dönem katsayıları ise, $\beta_{1}, \beta_{2}, \beta_{3}$ olarak verilmiștir.

Bu çalıșmada Schorderet $(2002,2003)$ tarafindan olușturulan ve Shin ve diğerlerinin (2014) katkılarıyla sunulan NARDL modeli yardımıyla reel dolaylı ve dolaysız vergi değișimlerin ekonomik aktiviteler üzerindeki asimetrik etkisi incelenmektedir. Bu yöntemde RDIRECT ve RINDIRECT değișkenleri pozitif ve negatif șoklar olmak üzere iki değișkene ayrılmaktadır. Böylece RDIRECT ${ }^{+}$, RDIRECT $^{-}$, RINDIRECT $^{+}$ve RINDIRECT - değișkenleri pozitif ve negatif șokların kısmı toplamından olușur ve așağıdaki gibi hesaplanmaktadırlar: 


$$
\begin{aligned}
& \operatorname{RDIRECT}_{t}^{+}=\sum_{i=1}^{t} \Delta \mathrm{RDIRECT}_{i}^{+}=\sum_{i=1}^{t} \max \left(\triangle \mathrm{RDIRECT}_{i}, 0\right) \\
& \operatorname{RDIRECT}_{t}^{-}=\sum_{i=1}^{t} \Delta \operatorname{RDIRECT}_{i}^{-}=\sum_{i=1}^{t} \min \left(\Delta \operatorname{RDIRECT}_{i}, 0\right) \\
& \operatorname{RINDIRECT}_{t}^{+}=\sum_{i=1}^{t} \Delta \operatorname{RINDIRECT}_{i}^{+}=\sum_{i=1}^{t} \max \left(\triangle \operatorname{RINDIRECT}_{i}, 0\right) \\
& \operatorname{RINDIRECT}_{t}^{-}=\sum_{i=1}^{t} \Delta \operatorname{RINDIRECT}_{i}^{-}=\sum_{i=1}^{t} \min \left(\triangle \text { RINDIRECT }_{i}, 0\right)
\end{aligned}
$$

Böylece uzun dönem ilișkiyi gösteren (1) numaralı denklem așağıdaki gibi yazılmaktadır:

$$
\begin{gathered}
\operatorname{IPI}_{t}=\alpha_{0}+\alpha_{1}^{+} \mathrm{RDIRECT}_{t}^{+}+\alpha_{1}^{-} \mathrm{RDIRECT}_{t}^{-}+\alpha_{2}^{+} \mathrm{RINDIRECT}_{t}^{+}+\alpha_{2}^{-} \mathrm{RINDIRECT}_{t}^{-} \\
+\epsilon_{t}
\end{gathered}
$$

Kısa dönem ve uzun dönem asimetrik ilișkiyi gözlemleme amacıyla (3) numaralı denklem așağıda șekle dönüșür:

$$
\begin{aligned}
\Delta \mathrm{IPI}_{t}=\psi+ & \eta_{0} \mathrm{IPI}_{t-1}+\eta_{1}^{+} \operatorname{RDIRECT}_{t-1}^{+}+\eta_{1} \mathrm{RDIRECT}_{t-1}^{-1} \\
& +\eta_{2}^{+} \mathrm{RINDIRECT}_{t-1}^{+} \quad(6)+\eta_{2}^{-} \operatorname{RINDIRECT}_{t-1}^{-}+\sum_{j=1}^{p} \beta_{1 j} \Delta \mathrm{IPI}_{t-j} \\
& +\sum_{j=0}^{q}\left(\beta_{2 j}^{+} \Delta \operatorname{RDIRECT}_{t-j}^{+}+\beta_{2 j} \Delta \operatorname{RDIRECT}_{t-j}^{-}\right) \\
& +\sum_{j=0}^{m}\left(\beta_{3 j}^{+} \Delta \operatorname{RINDIRECT}_{t-j}^{+}+\beta_{3 j}^{-} \Delta \operatorname{RINDIRECT}_{t-j}^{-}\right)+\gamma_{1} \text { DUMMY }_{t}+e_{t}
\end{aligned}
$$

Burada $\quad \psi=\beta_{0}-\theta \alpha_{0}, \eta_{0}=\theta, \eta_{1}^{+}=-\theta \alpha_{1}^{+}, \eta_{1}^{-}=-\theta \alpha_{1}^{-}, \eta_{2}^{+}=-\theta \alpha_{2}^{+}$ ve , $\eta_{2}^{-}=-\theta \alpha_{2}^{-}$geçerlidir. Ekonomik aktiviteler, reel dolaysız ve dolaylı pozitif ve negatif șoklarının uzun dönem katsayıları sırasıyla $\theta=\eta_{0}, \alpha_{1}^{+}=\frac{-\eta_{1}^{+}}{\theta}, \alpha_{1}^{-}=\frac{-\eta_{1}^{-}}{\theta}, \alpha_{2}^{+}=\frac{-\eta_{2}^{+}}{\theta}, \alpha_{2}^{-}=\frac{-\eta_{2}^{-}}{\theta}$ ve kısa dönem katsayıları $\beta_{2}^{+}, \beta_{2}^{-}, \beta_{3}^{+}$ve $\beta_{3}^{-}$olarak elde edilmektedir. (6) numaralı denklem ile asimetrik ilișkinin sadece uzun dönemde veya sadece kısa dönemde geçerli olduğunu iddia edilebilmektedir. Shin vd. (2014) takiben tamamen asimetrik ilișki gösteren (6) numaralı denklem, (7) ve (8) numaralı denkleme ayrıștırılmaktadır.

Asimetri sadece kısa dönemde geçerli ise, așağıdaki (7) numaralı denklem yazılabilmektedir: 


$$
\begin{aligned}
\Delta \mathrm{IPI}_{t}=\psi+ & \eta_{0} \mathrm{IPI}_{t-1}+\eta_{1} \text { RDIRECT }_{t-1}+\eta_{2} \text { RINDIRECT }_{t-1}+\sum_{j=1}^{p} \beta_{1 j} \Delta \mathrm{IPI}_{t-j} \\
& +\sum_{j=0}^{q}\left(\beta_{2 j}^{+} \Delta \operatorname{RDIRECT}_{t-j}^{+}\right. \\
& \left.+\beta_{2 j}^{-} \Delta \operatorname{RDIRECT}_{t-j}^{-}\right) \\
& +\sum_{j=0}^{m}\left(\beta_{3 j}^{+} \Delta \mathrm{RINDIRECT}_{t-j}^{+}+\beta_{3 j}^{-} \Delta \mathrm{RINDIRECT}_{t-j}^{-}\right)+\gamma_{1} \mathrm{DUMMY}_{t}+e_{t}
\end{aligned}
$$

Asimetri sadece uzun dönemde geçerli ise, așağıdaki (8) numaralı denklem yazılabilmektedir:

$$
\begin{aligned}
\Delta \mathrm{IPI}_{t}=\psi+ & \eta_{0} \mathrm{IPI}_{t-1}+\eta_{1}^{+} \mathrm{RDIRECT}_{t-1}^{+}+\eta_{1}^{-} \mathrm{RDIRECT}_{t-1}^{-}+\eta_{2}^{+} \mathrm{RINDIRECT}_{t-1}^{+} \\
& +\eta_{2}^{-} \text {RINDIRECT }_{t-1}^{-}+\sum_{j=1}^{p} \beta_{1 j} \Delta \mathrm{IPI}_{t-j} \\
& +\sum_{j=0}^{q} \beta_{2 j} \Delta \operatorname{RDIRECT}_{t-j}+\sum_{j=0}^{m} \beta_{3 j} \Delta \text { RINDIRECT }_{t-j}+\gamma_{1} \text { DUMMY }_{t}+e_{t}
\end{aligned}
$$

\section{Veriler}

Modelde T.C. Merkez Bankası veri tabanından 01:2006/ 04:2016 tarihlerini kapsayan dönem için aylık olarak elde edilmiș veriler kullanılmaktadır. Dolaylı ve dolaysız vergi gelirleri, üretici fiyat endeksi kullanılarak reel duruma getirilmiștir. Dolaysız vergi gelirleri, yılın belirli dönemleri tahsil edildiğinden dolayı takvim etkisi içermektedir. Takvim etkisine rağmen bağımsız değișken olarak modelde bulunduğundan ve kukla değișken söz konusu takvim etkisini gidermek için kullanıldığında bağımsız değișkenler arasında çoklu bağlantı sorunu olușabileceğinden, modelde mevsimsellik için özel bir kukla eklenmemiștir. 2008 yılı krizini temsilen kukla değișkeni modelde bulunmaktadır. Tablo 1'de modelde kullanılan verilerin tanımlayıcı istatistikleri gösterilmektedir.

Tablo 1. Değișkenlere ilișkin tanımlayıı istatistikler

\begin{tabular}{|l|r|r|r|}
\hline Değisken & \multicolumn{2}{c|}{ PPI } & \multicolumn{1}{c|}{ INDIRECT } \\
\hline Ortalama & 108.2963 & 14153880 & 6821045 \\
\hline Medyan & 108.1450 & 13209571 & 5976103 \\
\hline Minimum & 71.42000 & 6006292 & 2138115 \\
\hline Maksimum & 147.0100 & 27217343 & 16263735 \\
\hline Standart Sapma & 22.56791 & 5554521 & 3436026 \\
\hline Gözlem Sayısı & 124 & 124 & 124 \\
\hline Skewness & 0.155480 & 0.449468 & 0.813828 \\
\hline Kurtosis & 1.781005 & 2.002104 & 2.896806 \\
\hline Jarque-Bera & $8.176997 * *$ & $9.320065 *$ & $13.74287 *$ \\
\hline
\end{tabular}

Not: * ve ** sırasıyla; \%1 ve \%5 seviyesinde serinin normal dağılmadığını ifade eder. Tablo tarafımca düzenlenmiștir. 


\section{Ampirik Sonuçların Değerlendirilmesi}

ARDL modeli için değișkenlerin sıfır veya birinci dereceden eșbütünleșik olmaları gereklidir. Tablo 2 'de değișkenlerin durağanlık sınamaları verilmektedir.

Tablo 2. Verilerin birim kök testleri

\begin{tabular}{|c|c|c|c|c|c|c|}
\hline Değiș & eviye & Model & Augmented Dick & Fuller (ADF) & Phillips-Pe & on (PP) \\
\hline & & & t-Statistic & Prob. & Adj. t-Stat & Prob. \\
\hline PPI & Seviye & Sabit & -0.383603 & 0.907300 & -0.223053 & 0.931300 \\
\hline $\mathrm{PPI}$ & cinci $\mathrm{B}$ & abit & -7.352831 * & 0.000000 & $-7.220874^{*}$ & 0.000000 \\
\hline PPI & Seviye & Sabit ve Trend & $-3.377483^{* * *}$ & 0.059200 & -2.582701 & 0.289000 \\
\hline PPI & inci Fark & abit ve Trend & & 00 & $-7.188422^{*}$ & 000 \\
\hline INDIRECT & Seviye & Sabit & 1.809306 & 0.999700 & -0.919627 & 0.779100 \\
\hline INDIRECT & Birinci Fark & Sabit & 3.092651 ** & 0.030000 & $-61.42845^{*}$ & 0.000100 \\
\hline INDIRECT & Seviye & Sabit & & 0.686800 & $-6.638986^{*}$ & 0.000000 \\
\hline INDIRECT & Birinci Fark & Sabit ve Trend & $-3.166397 * * *$ & 0.096700 & $-72.66334^{*}$ & 0.000100 \\
\hline DIRECT & Seviye & Sabit & 2.586795 & 1.000000 & $-10.41891 *$ & 0.000000 \\
\hline DIRECT & Birinci Fark & Sabit & $-6.831354^{*}$ & 0.000000 & $-86.44644^{*}$ & 0.000100 \\
\hline DIRECT & Seviye & Sabit ve Trend & -0.298913 & 0.989800 & $-18.56723^{*}$ & 0.000000 \\
\hline DIRECT & Birinci Fark & Sabit ve Trend & -7.541091 * & 0.000000 & $-84.95492^{*}$ & 0.000100 \\
\hline
\end{tabular}

Nor: ${ }^{*},{ }^{* *}$ ve ${ }^{* *}$ sırasıyla; \%1, \%5 ve \%10 seviyesinde durağanlığı ifade eder. Tablo tarafımca düzenlenmiștir.

Yukardaki tabloda görüldüğü gibi değișkenlerin tümü seviyede veya birinci farkları alındığında durağan hale gelmektedir. Böylece bu değișkenlerin modelde kullanılmalarında bir sakınca bulunmamaktadır. Bu çalıșmada kullanılan tüm değișkenler, birinci veya düzeyde eșbütünleșmiș oldukları için doğrusal olmayan gecikmesi dağıtılmıș otoregresif modelin kullanılmasında sakınca bulunmamaktadır. Aylık verilerle yapılan tahmin için maksimum gecikme sayısı 12 olarak ele alınmıș ve uygun gecikme sayısı her bir model için 2028 iterasyon uygulanarak Schwarz bilgi ölçütü yardımıyla bulunmuștur.

Tablo 3'te, üç ayrı model için tanı ve tahmin sonuçları verilmektedir. Modelin simetrik tahmin sonucu birinci sütunda, kısa ve uzun dönem asimetri analiz sonucu ikinci ve kısa dönem simetri uzun dönem asimetri sonucu ise, üçüncü sütunda verilmiștir. Bu sonuçlara bakıldığında tüm modellerde eșbütünleșme ilișkisine ait sonuçların istatistiksel olarak anlamlı oldukları görülmektedir. Simetrik varsayım (ARDL) için hesaplanan $\mathrm{F}$ değerine bakıldığında uzun dönemde bir eșbütünleșme ilișkisi saptanmıștır. Kısa ve uzun dönem ilișkilere bakıldığında ise ilginç bir durum ortaya çıkmaktadır. Uzun dönemde ekonomik aktivitelerin dolaylı ve dolaysız vergi geliri ile pozitif ilișkiye sahip olduğu görülmektedir 
ancak dolaysız vergiler için kısa dönemde negatif bir ilișki ortaya çıkmaktadır. Bu durumda değișkenler arasında mevcut olan asimetrik ilișki olasılığının incelenmesi önem kazanmaktadır. Asimetrik ilișki göz ardı edildiğinde modelin yanıltıcı sonuçlar vermesi beklenmektedir. Bu nedenle modelde bulunan tüm değișkenler asimetrik olarak modele dâhil edilip sonuçlar üçüncü sütunda verilmiștir. Bu modelde de değișkenlerin çoğu istatistiksel olarak anlamlı bulunmuș ve tanısal açıdan bir sorun bulunamamıștır. Uzun dönemde "simetri vardır" boș hipotezi reddedilirken kısa dönemde "asimetri yoktur" boș hipotezi kabul edilmiștir. Böylece model istatistiksel olarak geçerliliğini kaybetmiștir. Bu noktada sadece uzun dönemde asimetri varlığına izin veren modelin tahmini yapılmıș ve sonuçlar Tablo 3'ün son sütununda verilmiștir.

Tablo 3. Modelin tahmin sonuçları

\begin{tabular}{|c|c|c|c|}
\hline Değișken & Simetrik & LR \& SR Asimetri & LR Asimetri \\
\hline $\mid \mathrm{PI}(-1)$ & $-0.482423^{*}$ & $-0.412804^{*}$ & $-0.424724^{*}$ \\
\hline RDIRECT(-1) & $2.13 \mathrm{E}-06$ ** & & \\
\hline RINDIRECT(-1) & $1.37 \mathrm{E}-06^{*}$ & & \\
\hline RDIRECT_N(-1) & & $-7.08 \mathrm{E}-07$ & $-7.66 \mathrm{E}-07$ \\
\hline RDIRECT_P(-1) & & $-1.40 \mathrm{E}-06$ ** & $-1.43 \mathrm{E}-06^{*}$ \\
\hline RINDIRECT_N(-1) & & $-1.40 \mathrm{E}-08$ & $8.72 \mathrm{E}-08$ \\
\hline RINDIRECT_P(-1) & & $2.19 \mathrm{E}-06^{*}$ & $2.20 \mathrm{E}-06^{*}$ \\
\hline $\mathrm{D}(\mathrm{IPI}(-1))$ & $-0.358026^{*}$ & $-0.792968^{*}$ & -0.787158 * \\
\hline $\mathrm{D}(\mathrm{IPI}(-2))$ & & $-0.627396^{*}$ & $-0.626436^{*}$ \\
\hline $\mathrm{D}(\mathrm{IPI}(-3))$ & & $-0.674205^{*}$ & -0.678761 * \\
\hline $\mathrm{D}(\mathrm{IPI}(-4))$ & & $-0.650433^{*}$ & $-0.646675^{*}$ \\
\hline $\mathrm{D}(\mathrm{IPI}(-5))$ & & $-0.548589 *$ & -0.539384 * \\
\hline $\mathrm{D}(\mathrm{IPI}(-6))$ & & $-0.447218^{*}$ & $-0.443252 *$ \\
\hline $\mathrm{D}(\mathrm{IPI}(-7))$ & & $-0.383239 *$ & -0.372076 * \\
\hline $\mathrm{D}(\mathrm{IPI}(-8))$ & & $-0.341303^{*}$ & $-0.326380^{*}$ \\
\hline $\mathrm{D}(\mathrm{IPI}(-9))$ & & $-0.383069 *$ & $-0.366126^{*}$ \\
\hline $\mathrm{D}(\mathrm{IPI}(-10))$ & & -0.581071 * & -0.564801 * \\
\hline $\mathrm{D}(\mathrm{IPI}(-1) 1))$ & & $-0.488855^{*}$ & $-0.470573^{*}$ \\
\hline $\mathrm{D}$ (RDIRECT) & $-1.38 \mathrm{E}-06^{*}$ & & $-8.25 \mathrm{E}-07^{*}$ \\
\hline D(RDIRECT(-1)) & $-5.31 \mathrm{E}-06^{*}$ & & \\
\hline $\mathrm{D}(\mathrm{RDIRECT}(-2))$ & $-4.77 \mathrm{E}-06^{*}$ & & \\
\hline $\mathrm{D}(\mathrm{RDIRECT}(-3))$ & $-3.36 \mathrm{E}-06^{*}$ & & \\
\hline D(RDIRECT_N) & & $-7.14 \mathrm{E}-07$ & \\
\hline D(RDIRECT_P) & & $-8.94 \mathrm{E}-07 *$ * & \\
\hline $\mathrm{D}$ (RINDIRECT) & $1.69 \mathrm{E}-06^{*}$ & & 1.57E-06* \\
\hline $\mathrm{D}$ (RINDIRECT_N) & & $1.31 \mathrm{E}-06$ *** & \\
\hline D(RINDIRECT_P) & & $1.73 \mathrm{E}-06^{*}$ & \\
\hline $\mathrm{C}$ & $22.57295^{*}$ & $40.24116^{*}$ & $41.39684^{*}$ \\
\hline
\end{tabular}




\begin{tabular}{|l|c|c|c|}
\hline DUMMY & $-10.04269^{*}$ & $-16.50197^{*}$ & $-16.71149^{*}$ \\
\hline ECM(-1) & $-0.399032^{*}$ & $-0.382936^{*}$ & $-0.351614^{*}$ \\
\hline Model & ARDL(1,3,0) & ARDL(11,0,0) & ARDL(11,0,0) \\
\hline F-statistic & $28.85207^{*}$ & $21.25718^{*}$ & $23.92243^{*}$ \\
\hline Sinır F Değeri & 8.558772 & 10.27229 & 10.50176 \\
\hline Sinır Değeri & $3.79-4.85$ & $2.86-4.01$ & $2.86-4.01$ \\
\hline Jarque-Bera & 0.732636 & 2.044463 & 2.246067 \\
\hline Heteroskedasticity F & 1.156944 & 1.687671 & 1.581089 \\
\hline RDIRECT $W_{\text {IR }}$ & & $10.09384^{*}$ & $12.68774^{*}$ \\
\hline RINDIRECT $W_{L R}$ & & $11.33376^{*}$ & $14.35991^{*}$ \\
\hline RDIRECT $W_{S R}$ & & 0.060023 & \\
\hline RINDIRECT $W_{S R}$ & & 0.186418 & \\
\hline
\end{tabular}

Not: ${ }^{*},{ }^{* *}$ ve ${ }^{* * *}$ sırasıyla; \%1, \%5 ve \%10 seviyesinde anlamlılı̆ı̆ ifade eder. Tablo tarafımca düzenlenmiștir.

Sadece uzun dönem asimetrik değișkenleri içeren model, uzun dönem simetri testleri geçerli olmadığı için asimetrik ilișki uzun dönemde reddedilememiștir. Kısa dönem asimetri içeren modellerde 6 ve 7 numaralı denklemler) de değișkenin simetri hipotezi kabul edildiğinden kısa dönem asimetri reddedilmektedir. ARDL modellinin tahmin sonuçlarının geçerliliği için gerekli olan testlere bakıldığında hata terimlerinin normal dağıldığı, içsel bağıntı ve değișen varyans sorunlarının bulunmadığı görülmektedir. Ayrıca CUSUM ve CUSUMQ testleri de modelin istikrarlı olduğunu göstermektedir. Uzun dönem katsayılara bakıldığında vergilerde azalmalar istatistiksel olarak anlamlı bulunmazken vergilerdeki artıș uzun dönemde anlamlı bulunmuștur. Uzun dönemde asimetrik ilișkiyi gösteren model ve simetrik model sonuçlarının daha iyi anlașılması için așağıdaki șekillere bakılmasında fayda vardır.

Șekil 1. Simetrik model için dolaylı ve dolaysız vergi dinamikleri
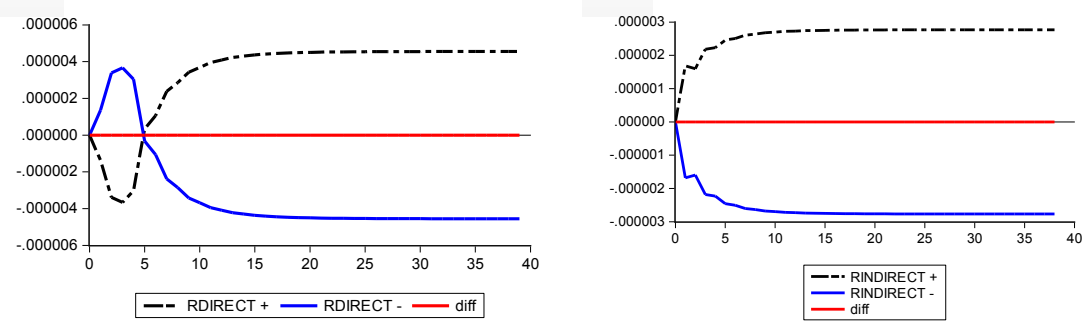
Șekil 2. Uzun dönem asimetrik model için dolaylı ve dolaysız vergi dinamikleri
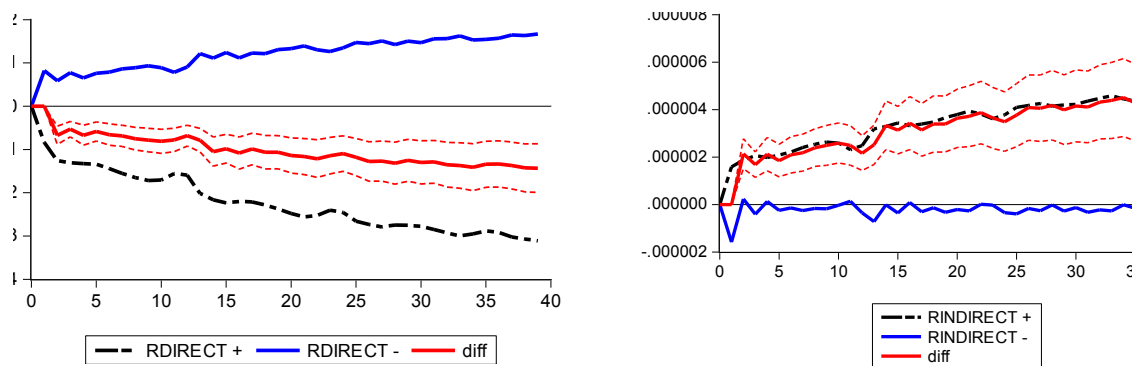

Șekil (1) simetrik analizin dinamiklerini açıkça ortaya koymaktadır. Dolaysız vergilere bakıldığında kısa dönemdeki etki, uzun dönemdeki etki ile çelișmektedir. Kısa dönemde vergilerin (dolaysız) artıșı ekonomik aktivitelere olumsuz etki yaparken uzun dönemde bunun tersi bir durum ortaya çıkmaktadır. Dolaysız vergilerde bir artıș ekonomik aktivitelerde bir azalmaya yol açmaktadır ancak bu etki üç dönem sonra değișmekte ve pozitif yöne doğru hareket etmektedir. Model simetrik olduğundan dolayı aynı durum dolaysız vergilerin azalıșında da geçerlidir. Dolaylı vergilerin dinamiğine bakıldığında ise, hem kısa hem de uzun dönemde ilișki aynı yönde devam etmekte ve dolaylı vergilerde bir artıș ekonomik aktivitelerde bir artıșa yol açmaktadır.

Șekil (2) asimetrik model dinamiklerini göstermektedir. Yapılan testlerde kısa dönemde asimetri reddedilmiștir. Ancak uzun dönemde asimetrik bir ilișkinin varlığı kabul edilmiștir. Șekilde görüldüğü gibi dolaysız vergilerde bir artıș, vergi gelirlerinin azalıșına göre farklılık göstermektedir. Hem uzun hem de kısa dönemde dolaysız vergilerdeki artıșın etkisinin, azalıșının etkisine göre daha fazla olduğu görülmektedir. Ancak tahmin sonucuna göre dolaysız vergiler için artıșlar istatistiksel olarak anlamlı fakat azalıșlar istatistiki olarak anlamlı bulunamamıștır. Bu nedenle sadece vergilerdeki artıșın uzun dönemdeki etkisini yorumlama olanağımız vardır. Kısa ve uzun dönemde dolaysız vergilerde bir artıș ekonomik aktiviteler üzerine olumsuz etki yapmaktadır ancak ekonomik aktivitelerin artıșı için dolaysız vergilerde azalma etkisiz olacaktır. Dolaylı vergiler için de benzer yorumların yapılması mümkündür ancak dolaysız vergilerin aksine ekonomik aktiviteler ile dolaylı vergiler arasında pozitif bir ilișki mevcuttur. Dolaylı vergilerde bir artıș ekonomik aktiviteleri artırırken, vergilerde azalıs etki yapmamaktadır. Ayrıca istatistiksel olarak dolaylı vergilerin artıșı ekonomik aktiviteler üzerindeki etkisi anlamlı iken azalıșı anlamlı bulunmamıștır. 


\section{Sonuç}

Devletin cari ve yatırım harcamalarını finanse etmek için kullanılan vergiler dolayısı ile vergi politikaları çeșitli sosyal ve ekonomik etkilere de sebep olmaktadır. Vergilerin sadece harcamaların finansman aracı olarak görülmesi ve diğer etkilerinin dıșlanması hatalı sonuçlara sebep olabilmektedir. Keynesyen iktisat okulunun düșüncelerine göre, vergi oranlarında artıș hane halklarının harcanabilir gelirini azaltmaktadır. Gelirdeki bu azalıș ise, tüketici talebini azaltarak piyasalar üzerinde negatif etki yaratmaktadır. Eksik istihdamda olan bir ekonomide talepte meydana gelen daralma ise, üretimde azalmaya neden olmaktadır.

Çalıșma kapsamında olușturulan model önce ARDL zaman serisi modeli yardımı ile tahmin edilmiștir. Doğru yorumların yapılması için analizde kullanılan değișkenler arasında asimetrik ilișki varlığı sınanması gerekmektedir. Böylece model, yapısı belirlendikten sonra dolaylı ve dolaysız vergilerin etkileri ayrı ayrı incelenmesi mümkün olmuștur. Uygulanan testler sonucunda modelin tanı ve tahmin sonuçları, tanısal bir problem saptanmamıș ve değișkenler istatistiki olarak anlamlı bulunmuștur.

Sonraki așamada hem dolaylı hem de dolaysız vergi ile ekonomik aktiviteler arasındaki ilișki, asimetri varsayımı altında analiz edilmiș ve asimetrik ilișkiye rastlanmıștır. Bu bağlamda her iki tür verginin uzun dönemli ilișkinin sadece simetrik analiz altında yorumlanmasının yanlıș olacağı düșünülmüștür.

Dolaylı ve dolaysız vergiler ile sanayi üretimi arasında kısa dönemde doğrusal ve uzun dönemde doğrusal olmayan bir ilișkiye mevcuttur. Asimetrik analiz altında dolaylı ve dolaysız vergilerde uzun dönemde azalıșların, ekonomik aktiviteler üzerine etkisi istatistiki olarak anlamlı bulunmamıștır. Uzun dönemde artıș ile ilgili katsayı ise, istatistiki olarak anlamlı bulunmuștur. Bu sonuçlara göre uzun dönemde dolaylı ve dolaysız vergilerde artıșlar, üretim üzerinde negatif etki yaratır iken vergi gelirlerinde azalıșların etkisi aynı șekilde bir azalıșa neden olmamaktadır.

Sonuçlar iktisadi olarak değerlendirildiğinde kar ve gelir üzerinden alınan dolaysız vergilerde bir artıșın uzun dönem yatırım planlamalarını olumsuz yönde etkilediği düșünülmektedir. Ancak dolaysız vergilerde azalıșın ekonomik aktiviteleri arttırdığı varsayımı geçerli görünmemektedir. 
Dolaylı vergiler için de benzer yorumların yapılması mümkündür ancak dolaysız vergilerin aksine ekonomik aktiviteler ile dolaylı vergiler arasında istatistiki olarak anlamlı ve pozitif bir ilișki mevcuttur. Dolaylı vergi tahsilatında azalıș ile ilgili değișkenin katsayısı ise, istatistiki olarak anlamlı bulunmamıștır. Dolaylı vergi gelirlerinde bir artıș ekonomik aktiviteleri artırıken, vergilerde azalıș ise etki yapmamaktadır. Bu durum vergi yükü ile açıklanabilir, dolaylı vergilerde bir artıș tüketicilerin talebinin azalmasına yol açar ancak bu talep azalmasının bir bölümü yurtiçi üreticilere yansır ve bir bölümü de ithal mallar talebinde etkili olur. Böylece dolaylı vergilerdeki bir artıș, dolaysız vergilerin toplam vergi yükündeki payını düșürür ve talepteki azalıș tüketicinin ithal mal talebinden dolayı aynı oranda gerçekleșmez. Ayrıca tüketicilerden devlete geçen kaynaklar kamu harcamalarında kullanıldığında firmalara ait azalan talep telafi olunur. Ancak bu durum dolaylı vergilerin azalıșında geçerli gözükmemektedir.

Bu çalıșma bulgularına göre, makroekonomik değișkenler arasındaki ilișkilerin incelemesinde asimetrik analizlerin yapılması gerekliliği öne çıkmıștır. Ayrıca vergideki artıșların ekonomik aktivitelere etkili olduğu görünürken azalıșı anlamlı bir etki yapmadığı ortaya çıkmıștır. Dolaylı ve dolaysız vergi gelirlerinin, ekonomik aktiviteler üzerindeki etkisi halen tartıșmalı bir konudur. Ayrıca sanayi üretimindeki artıș ve azalıșlardan, vergi gelirlerine doğru ilișkinin de gelecekteki çalıșmalarda incelenmesi yararlı olacakıtı. Fakat olası asimetrik ilișkilerin de göz ardı edilmemesi, politika yapıcıları için daha doğru kararlar alabilmeleri hususunda yardımcı olacakıır. 


\section{KAYNAKCุA}

Açıkgöz, Ș. (2008). Türkiye'de vergi gelirleri, vergi yapisi ve iktisadi büyüme ilișkisi: 1968-2006. Ekonomik Yaklașım, 19(68), 91-113.

Aliyev, P., \& Hopoğlu, S. (2016). Vergilerin gelir dağılımı temelinde verimliliği. iktisadi Yenilik Dergisi, 3(2), 27-45.

Aydin, M., \& Türgay, T. (2011). Yoksullukla mücadelede vergi politikası. Süleyman Demirel Üni libf Dergisi, 16(1), 249-274.

Çalıkay, F. (2017). Milli gelirin vergi yükü üzerindeki etkileri: ARDL sınır testi yaklașımı ile Türkiye üzerine bir inceleme (1924-2014). Sosyoekonomi, 25(32), 169-169. https://doi.org/10.17233/sosyoekonomi.286478

Eren, M. V., Ergin Ünal, A., \& Aydın, H. İ. (2018). Türkiye'de vergi gelirleri ile ekonomik kalkınma arasındaki ilișki: Frekans alanı nedensellik analizi. Doğuș Üniversitesi Dergisi, 19(1), 1-18.

Göçer, İ., Mercan, M., Bulut, Ș., \& Dam, M. M. (2010). Ekonomik büyüme ile vergi gelirleri arasındaki ilișki: sınır testi yaklașımı. Dumlupınar Üniversitesi Sosyal Bilimler Dergisi, (28).

Gökbunar, A. (1997). Türk vergi sisteminde reform gereği. Içinde Prof.Dr. Nezihe SÖNMEZ'e Armağan, DEÜ iliBF Maliye Bölümü Yayını, İzmir (ss. 301-324).

Güvenek, B., Alptekin, V., \& Çetinkaya, M. (2010). Enflasyon ve dolaylı vergilerden elde edilen gelirler arasındaki ilișkinin var yöntemiyle analizi. Kamu-ls Dergisi, 11(3), 1-28.

Ilaboya, O. J., \& Mgbame, C. O. (2012). Indirect tax and economic growth. Research Journal of Finance and Accounting, 3(1 1), 70-83.

ilhan, G. (2007). Vergi ödemeyi etkileyen ekonomik faktörler. Akademik bakıș, (12), 1-13.

Juliana, M. I. (2018). Effect of tax administration and revenue on economic growth in Nigeria. International Journal of Innovative Finance and Economics Research, 6(1), 45-59.

Kahneman, D., \& Tversky, A. (1979). Prospect theory: an analysis of decision under risk daniel kahneman; Amos Tversky. Econometrica, 47(2), 263-292. http:// doi.org/10.1111/i.1536-7150.2011.00774.x

Karabulut, T. (2003). Laffer etkisinin türkiye uygulaması (1980-2003). Selcuk University Social Sciences Institute Journal, (16), 367-377.

Keynes, J. (1936). The general theory of employment, interest and money. London: Macmiillan. 2.1.2018 Tarihinde adresinden erișildi http://cas.umkc.edu/economics/people/facultyPages/kregel/courses/econ645/Winter2011/GeneralTheory.pdf

Koch, S. F., Schoeman, N. J., \& Tonder, J. J. (2005). Economic growth and the structure of taxes in south africa: 1960-2002. The South African Journal of Economics, 73(2), 190-210. http://doi.org/10.1111/i.1813-6982.2005.00013.x 
Mahmood, H., \& Chaudhary, A. R. (2013). Impact of FDI on tax revenue in Pakistan. Pakistan Journal of Commerce and Social Sciences, 7(1), 59-69. http:// doi.org/10.5829/idosi.wasj.2012.19.04.1645

Mamatzakis, E. C. (2005). The dynamic responses of growth to tax structure for Greece. Applied Economics Letters, 12(3), 177-180. http://doi. org/10.1080/1350485042000318420

Mercan, M., Göçer, I., Bulut, S., \& Dam, M. M. (2010). The relationship between economic growth and tax revenue: Bounds testing. Içinde 2nd International Symposium on Sustainable Development, June 8-9 2010. (ss. 626-636).

Munir, K., \& Sultan, M. (2016). Are Some Taxes Better for Growth in Pakistan?A Time Series Analysis (No. 68828).

Organ, ì., \& Ergen, E. (2017). Türkiye'de vergi yükünün ekonomik büyümeye etkileri üzerine bir çalıșma. Pamukkale Üniversitesi Sosyal Bilimler Enstitüsü Dergisi, (27).

Paksoy, S., \& Bakan, S. (2010). Türkiye'de uygulanan vergi politikaları ve ekonomik büyüme üzerine etkileri: (1980 sonrası). Elektronik Sosyal Bilimler Dergisi, 9(32), 150-170.

Pesaran, M. H., Shin, Y., \& Smith, R. J. (2001). Bounds testing approaches to the analysis of level relationships. Journal of Applied Econometrics, 16(3), 289326. http://doi.org/10.1002/jae.616

Schorderet, Y. (2002). A nonlinear generalization of cointegration: A note on hidden cointegration (No. 2002.03). Genève.

Schorderet, Y. (2003). Asymmetric cointegration (No. 2003.01). Cahiers du département d'économétrie, Faculté des sciences économiques et sociales, Université de Genève.

Shiller, R. J. (1993). Macro Markets: Creating Institutions for Managing Society's Largest Economic Risks. Clarendon Press.

Shiller, R. J. (2005). Irrational Exuberance (2nd Editio). Princeton University Press.

Shin, Y., Yu, B., \& Greenwood-nimmo, M. (2014). Modelling asymmetric cointegration and dynamic multipliers in a nonlinear ARDL framework. Içinde R. C. Sickles \& W. C. Horrace (Ed.), Festschrift in Honor of Peter Schmidt Econometric Methods and Applications (ss. 281-314). http://doi.org/10.1007/978-14899-8008-3

Siverekli Demircan, E. (2003). Vergilendirmenin ekonomik büyüme ve kalkınma yetkisi. Erciyes Üniversitesi Iktisadi ve İdari Bilimler Fakültesi Dergisi, (21), 97-116.

Susam, N., \& Oktayer, N. (2005). Türkiye ekonomisinde genel bütçe vergi gelirleri içinde dolaysız ve dolaylı vergiler (1995-2005). Atatürk Üniversitesi Iktisadi ve Idari Bilimler Dergisi, $21(2)$.

Temiz, D. (2008). Türkiye' de vergi gelirler ve ekonomik büyüme ilișkisi: 19602006 dönemi. Içinde 2. Ulusal iktisat Kongresi (ss. 1-18). Izmir.

Umutlu, G., Alizadeh, N., \& Erkılıç, A. Y. (2011). Maliye politikası araçlarından borçlanma ve vergilerin ekonomik büyümeye etkileri. Uludağ Üniversitesi iktisadi ve İdari Bilimler Fakültesi Dergisi, 5(1), 75-93. 